\title{
The Role and the Identity of the tknu in the Ancient Egyptian Funerals ${ }^{1}$ \\ Mohamed Ali Zienelabdein Ahmed \\ PhD candidate- Minia University
}

\section{Abstract:}

The $t k n u$ is one of the rituals that was performed in the ancient Egyptian funerals. From the Old Kingdom onwards, the rite was included in many funerary scenes. The New Kingdom scenes included most of the appearance of the rite. Scholars disagree on the interpretation of the role and the identity of the tknu. Pictorial and textual evidence will be presented to determine the identity of the $t k n u$; was the rite performed by a priest, statue or by an object? The paper also investigates how and why the rite was done during the funerals.

One of the funerary depictions that still pose questions about its role and identity is the tknu. It was one of the elements that appeared in the funerals depictions from the Old Kingdom to the Late Period. ${ }^{2}$ This rite was performed at the funerals of Saqqara and Thebes. The only evidence for the appearance of this rite in the Old Kingdom comes from the tomb of Ihy/ reused by Idut at Saqqara (pl. 1). ${ }^{3}$ In this tomb, which dates back to the early $6^{\text {th }}$ Dynasty, the $t k n u$ was represented for the first time ${ }^{4}$ then in two tombs of the $12^{\text {th }}$ Dynasty during the Middle Kingdom Period. ${ }^{5}$ Then, most of the depictions appeared in the New Kingdom Theban funerary scenes. This reflects the importance of this rite and how Thebes was the central place in which it was unfolded and developed. ${ }^{6}$

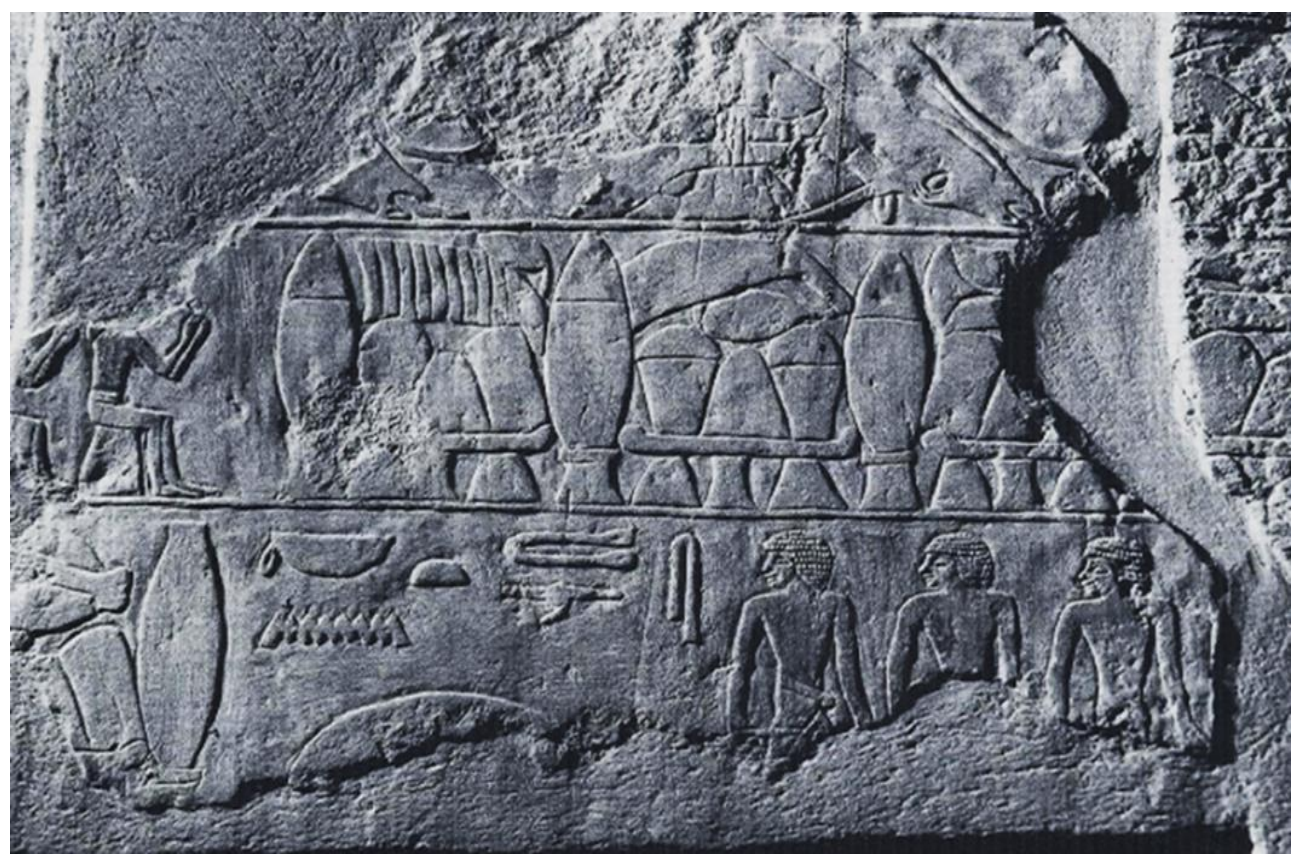

$P l$. 1. The tknu in the funeral scene in the tomb of Ihy/ reused by Idut at Saqqara (After, Kanawati \& Abder-Raziq, 2003, pl. 21). 
The $t k n u$ in the funerary scenes of the private Theban tombs took the shape of:

1- A shapeless mass or a pear shaped mass, which is positioned on a sledge that is being dragged by a number of people as TT55 (pl. 2). The shapemass was wrapped so that any resemblance to a human figure is not apparent. This was represented in some funeral scenes dating back to the Old Kingdom as in the tomb of the Mastaba of Ihy (Idut). The New Kingdom witnessed the most of depictions of this enigmatic figure. It was represented following the Canopic chest as in TT53, TT82, TT123, TT127, TT92, TT104, TT, A4 or in front of it like in TT55 or in other different positions in the funeral as in TT78 (pl. 3), TT178, TT49, and TT295.

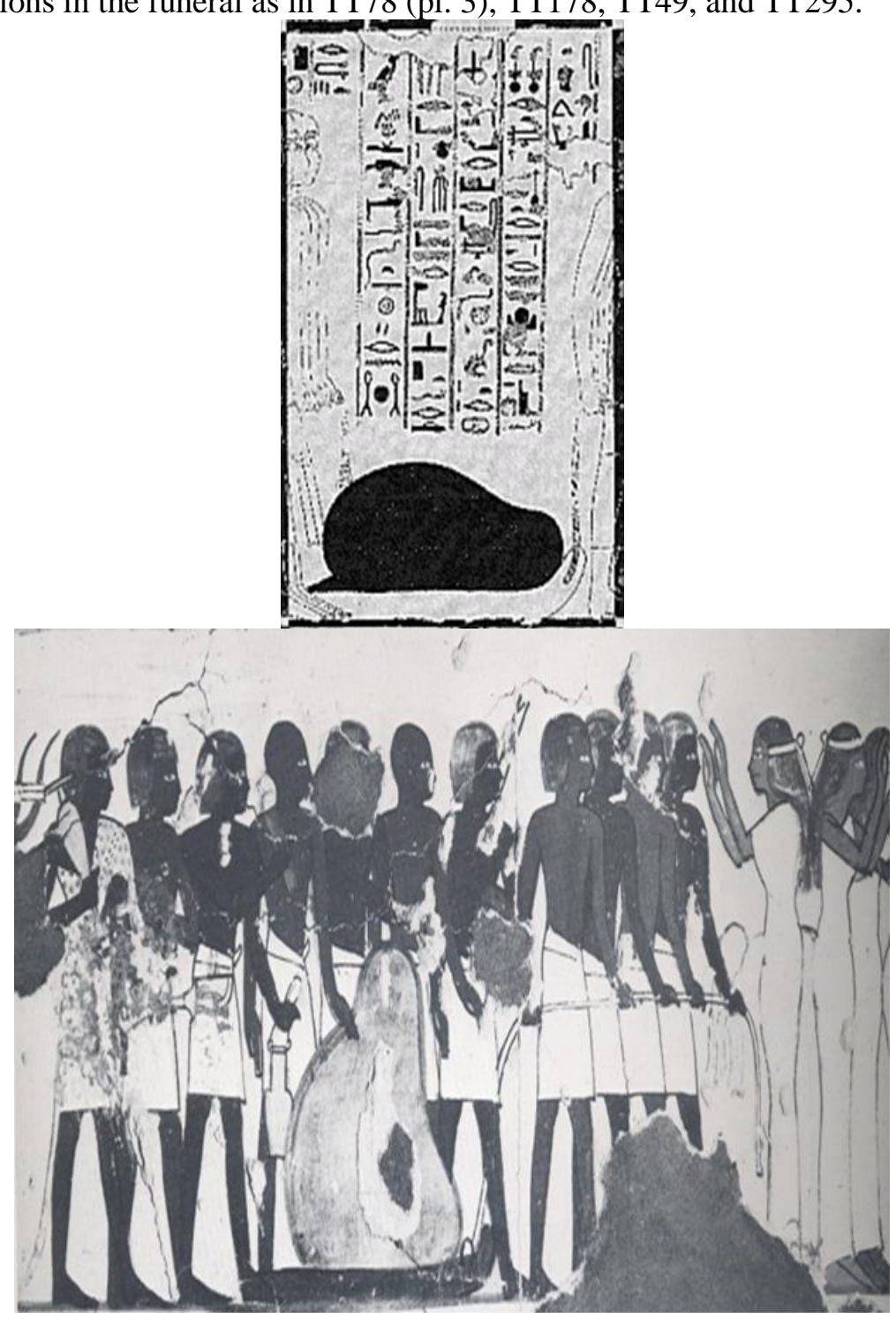

$P l$. 2. The $t k n u$ in the funerary procession in TT55 (After, Davies, N. de G., The tomb of the Vizier Ramose, London, 1941, pl. XXV). 
$P l$. 3. The $t k n u$ in the funerary procession in TT78 (After, Brack, A. \& Brack, A., "Das Grab des Haremheb, Theben Nr. 78" in $A V$ XXXV, Mainz am Rhein: Philipp von Zabern, 1980, Taf. 63a I).

2- A human shape wrapped in a hide (animal skin) or a shroud while the head and sometimes the hands are just showing through. It was depicted crouching either on a couch or a sledge. This was depicted in many scenes as TT100 (pl. 4) TT276 (pl. 5), TT284, TTC4, TT96, TT125, TT172, TT81, TT41 and TT66. 


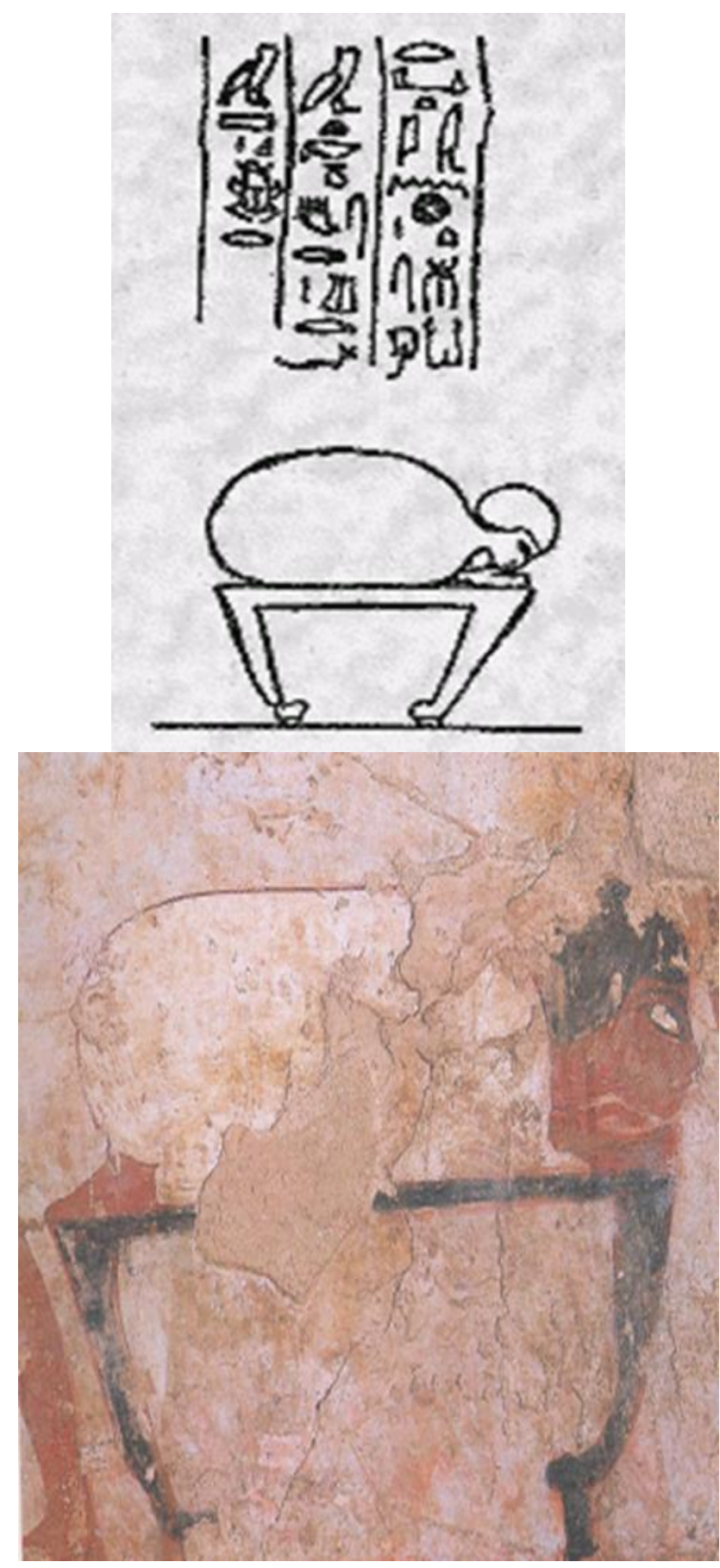

Pl. 4. The tknu in TT 100 (After, Davies, 1943, pl. LXXXIII) Pl. 5. The tknu in TT 276 (After, El-Shahawy, A., The Funerary Art of Ancient Egypt: A Bridge to the Realm of the Hereafter, American Univ in Cairo Press, 2005, fig. 42). 
3- A statuesque figure wrapped in a shroud or a hide (animal skin) seated on a couch or a sledge such as in TT15, TT60, TT12, TT260, TT39, TT42, TT17, TT39 (pl. 6), TT24 (pl. 7), and TT81.
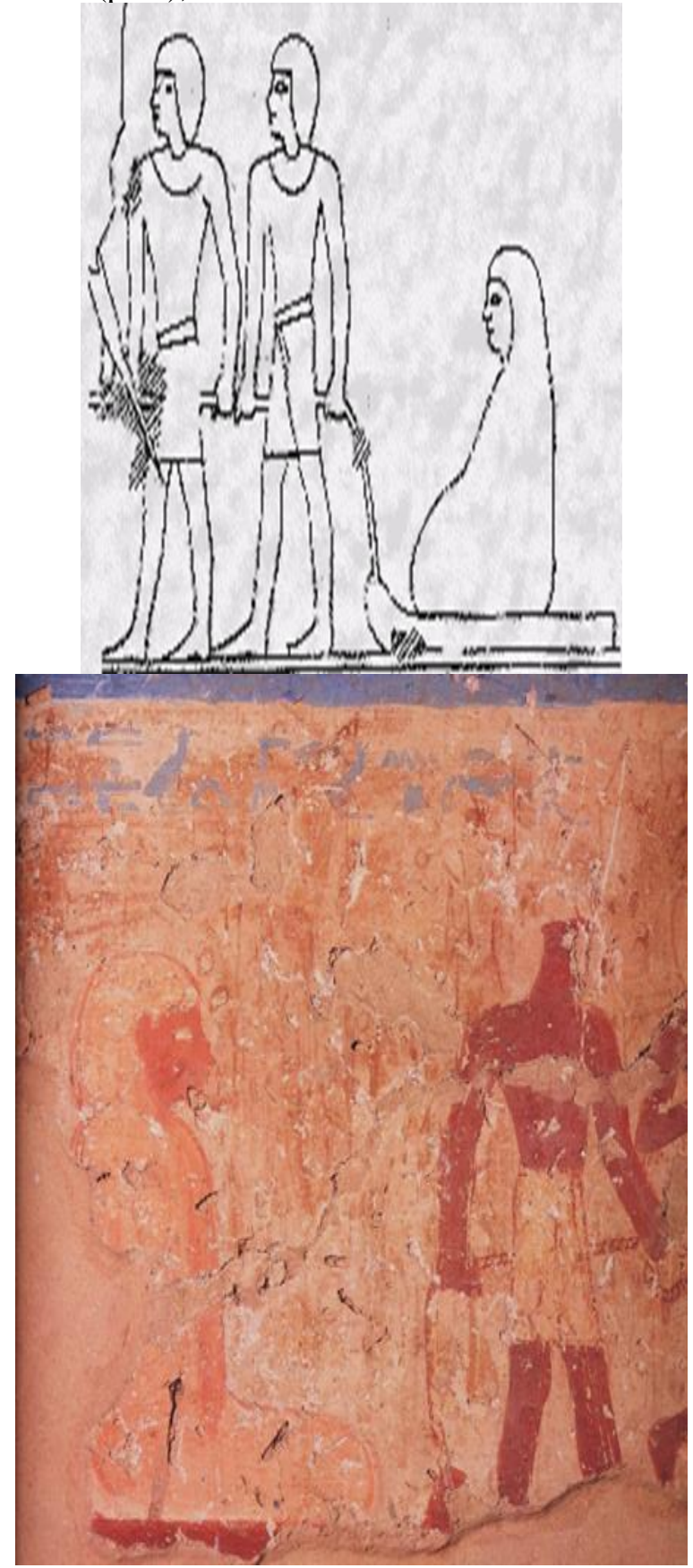

Pl. 6. The tknu in TT39 (After, Davies, 1923, Pl. XLVI). Pl. 7. The tknu in TT24 (After, El-Shahawy 2005, fig. 43). 
4- Human fully shaped crouching on a sledge without a shroud. Of all the depictions of the tknu in the funerals, The form as a complete human appeared only two times in the funeral scene of TT20 (pl. 8).

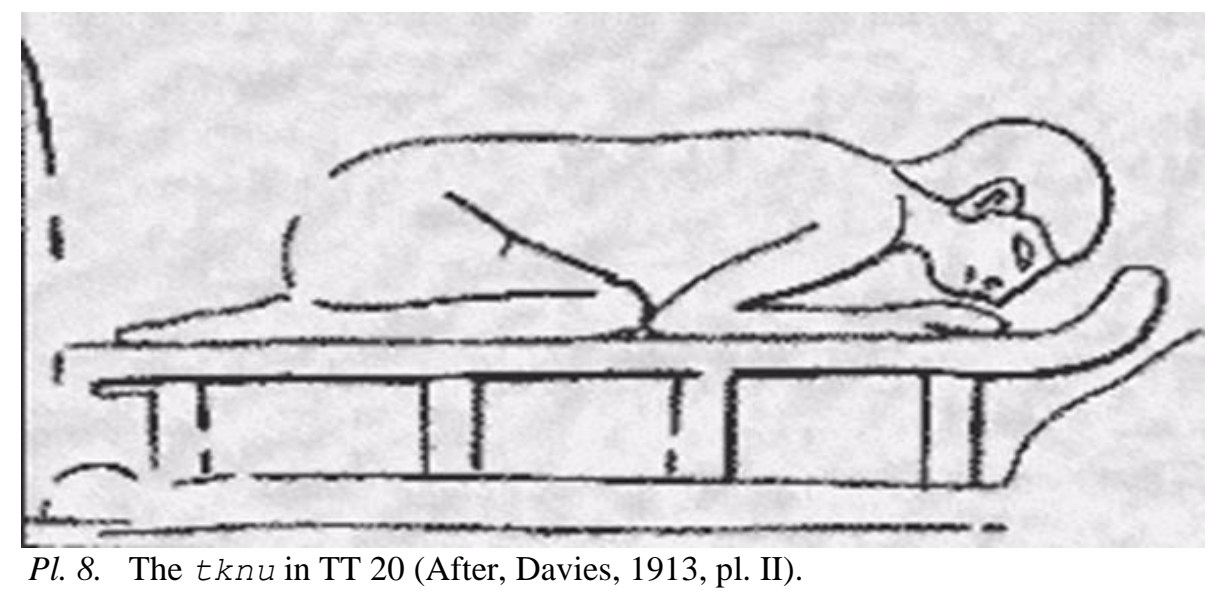

According to all these forms and its place in the funeral procession scenes we will try to identify the $t k n u$ role in the private New Kingdom funerals at Thebes;

As it was mentioned above the $t k n u$ and the Canopic chest were received by $M w w$ dancers during the funeral, which is depicted in many funerals as in; TT12, ${ }^{8}$, TT17, ${ }^{9}$ TT63, TT81, ${ }^{10}$ TT82, ${ }^{11}$ TT96, ${ }^{12}$ TT 276, TT24, TT42, TT172, TT260, ${ }^{13}$ TT179, ${ }^{14}$ and Tomb A $4 .{ }^{15}$ This action was understood that $t k n u$ was a part of the 'Butic burial' ceremony. ${ }^{16}$ The 'Butic burial' is related to the journey of the coffin to the ancient cult centers of Lower Egypt (Sais- Buto). ${ }^{17}$ Firstly, the deceased and the coffin were taken to the embalmment place then, came the 'Butic burial'. This ritual started with the journey of the coffin dragged by sledge to Sais, and after that from Sais to Buto. The procession was received by the Mww dancers at Buto then the journey continued towards Heliopolitan places. ${ }^{18}$

Griffiths suggested that the tknu was connected with "the Butic Burial". ${ }^{19}$ He further connects the ritual not with a human sacrifice, but a bull. As in many depictions showed the tknu in a ritual context of sacrificing a bull. ${ }^{20}$ For that the wraps, which covered the $t k n u$ is believed to be the skin of that sacrificed bull. The hide was called $m s k A,{ }^{21}$ which was mostly white that is linked with sun and the purity. ${ }^{22}$

In TT100 (pl. 4), there is a text reads: rdjt jj $n$ njwt mskA $m$ tknw $s D r X r . f m S \operatorname{Xpr}(j)$ "making the skin- mskA come to the city (the necropolis) with the $t k n w$, sleeping under it in the pool of khepri". The city refers to the necropolis, then the 'pool of kheperi' would be a 'pool of transformation'. ${ }^{23}$ Khepri was a god, who represented one of the three aspects of the sun god Re. ${ }^{24}$ Therefore, Khepri represented the sunrise, Re the noon and Atum the sunset. The verb Xpr means "come into being". The pool of Khepri was a way of transformation and a motivation for the power of the life cycle. The tknu was bringing all the 
powers of regeneration and rebirth that are represented in Khepri (rising sun). ${ }^{25}$ These powers were for restoring the vital functions of the body and bring it back to life during the Opening of the Mouth ritual.

It was also suggested that the $t k n u$ was a human figure wrapped in a skin of animal to inherit the vital magical force, that an animal possesses. ${ }^{26}$ It was also interpreted as a rebirth for the deceased that the skin was representing the womb of the mother, while the man inside is the embryo. ${ }^{27}$

As many depictions for the tknu showing it in the funeral procession together with the coffin and Canopic chest, Hornung argues that it was not a real personage, but a container for spare body parts. The extracted parts of the body that were not placed in Canopic jars were placed in an unusual-looking container which is the $t k n u .^{28}$

Kees thought that the tknu was a substitute image or a double for the deceased. It played a purifying role in the ritual because it drives towards himself all the evil forces in order to allow the deceased a peaceful transition to the afterlife. ${ }^{29}$

According to Delgado, the tknu represented a real character and not inanimate shape or a mere object. It was a ritualistic officiant or a priest who played this role. He argued that the sem priest was not this person who took the role of the tknu. The officiant who played this role was preparing his participation by rites, including ointments and incense. Two men were facing each other, one of them, perhaps a priest, holding in his hand a bowl while perfuming or outlining the eyes of the other participant. ${ }^{30}$ Then, by taking his performance objects that were a hide and a bed of sorts to make his role. The main function for the tknu was a sleep ritual, some kind of dream trance. ${ }^{31}$

The tknu appeared in the Opening of the Mouth ritual only in the New Kingdom scenes, which can be seen in TT21, TT69, TT42, ${ }^{32}$ TT100 (pl. 9 \& 10, 11), and TT295 ${ }^{33}$ (pl. 12). The sem priest was taking a part in the Opening of the Mouth rituals by playing different roles. One of these roles by lying down and then sitting on a couch in front of the mummy or the coffin of the deceased. He was wrapped in a cloak or an animal hide, his hands are put together on his breast while shoulders and feet are clearly marked under it. ${ }^{34}$

The $t k n u$ was making a sleep,$^{35}$ then waking up. This was interpreted that Osiris was resurrected after his death. ${ }^{36}$ The accompanying texts in these cases included "I have seen my father in all his manifestations" ${ }^{37}$ which refers that during sleeping of the sem who sees his father (the deceased) in all of his many forms, then he is awakened and reports his vision. ${ }^{38}$ In this rite, he visited the spirit world, where he recognized the deceased and was supplied with powers that will help him in the succeeding tasks of the Opening of the Mouth rituals for the deceased. He was looking for the soul of the deceased in the world spirit to bring it back to the body. ${ }^{39}$ After the end of this rite, the sem changed his role form a $t k n u$ to a normal sem priest with panther skin. ${ }^{40}$ 


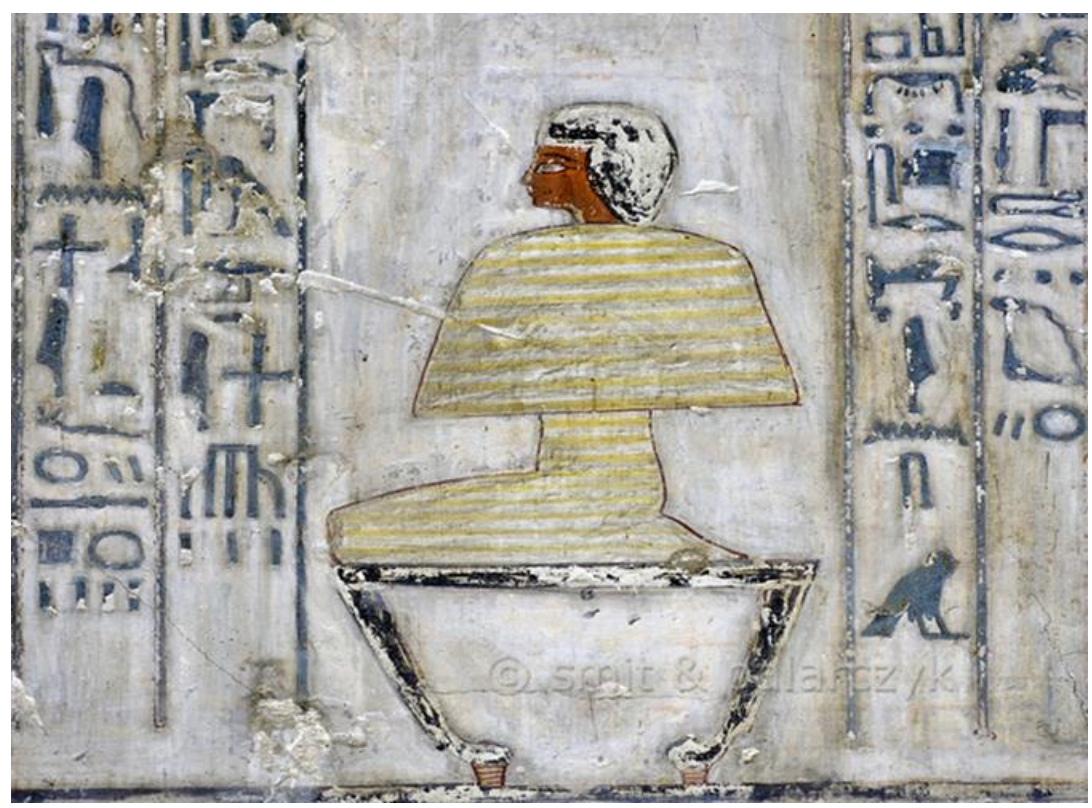

Pl. 9. The $t k n u$ in TT100 (After http://paulsmit.smugmug.com/Features/Africa/EgyptLuxor-tombs/26743236 bd7S6R/2239465347 gdDkfZn\#! $1=2239465347 \& \mathrm{k}=\mathrm{gdDkfZn}$ in 5/1/2015).

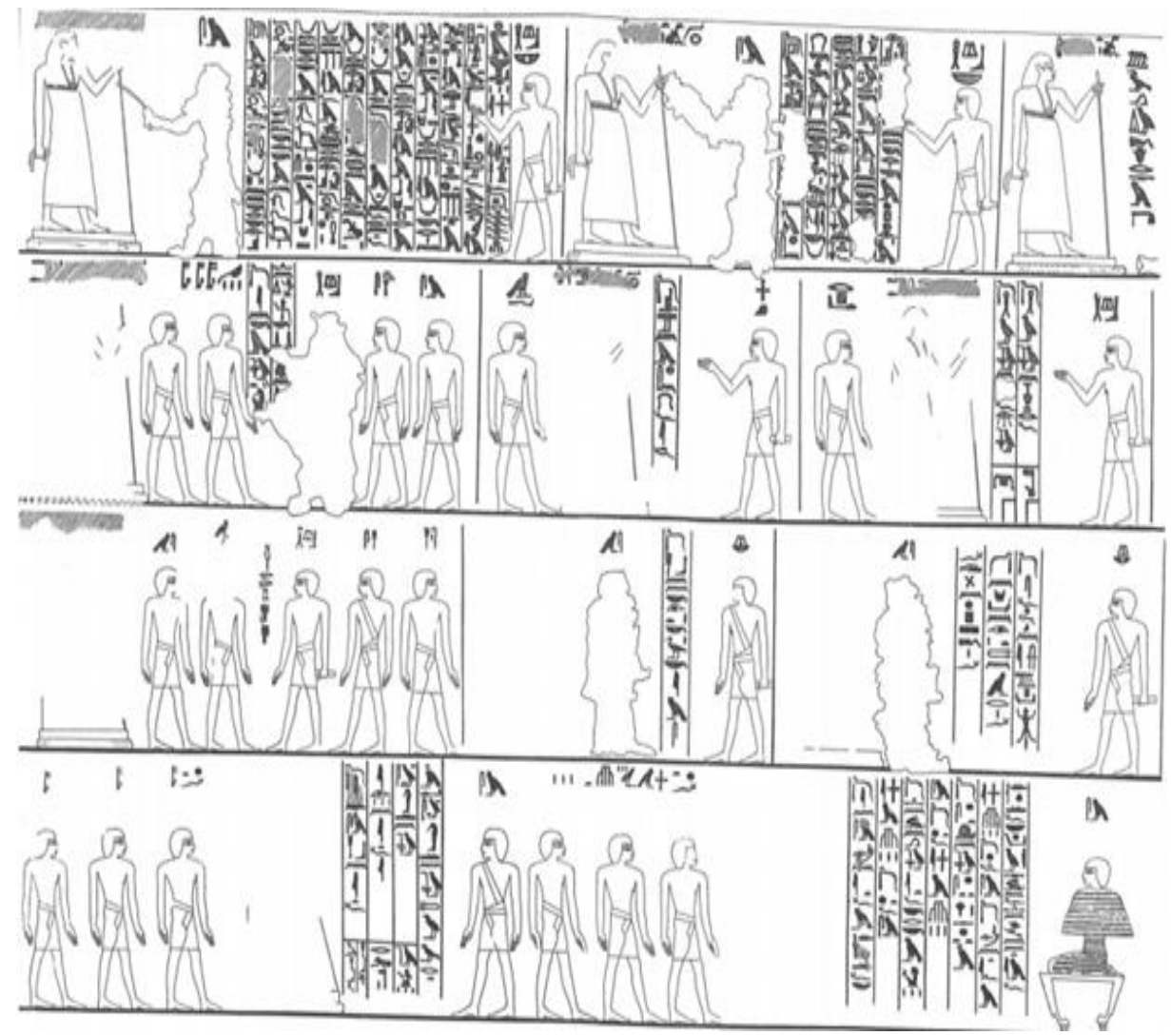


Pl. 10. The sem priest in TT 100 (Davies, 1943, Pl. CV).

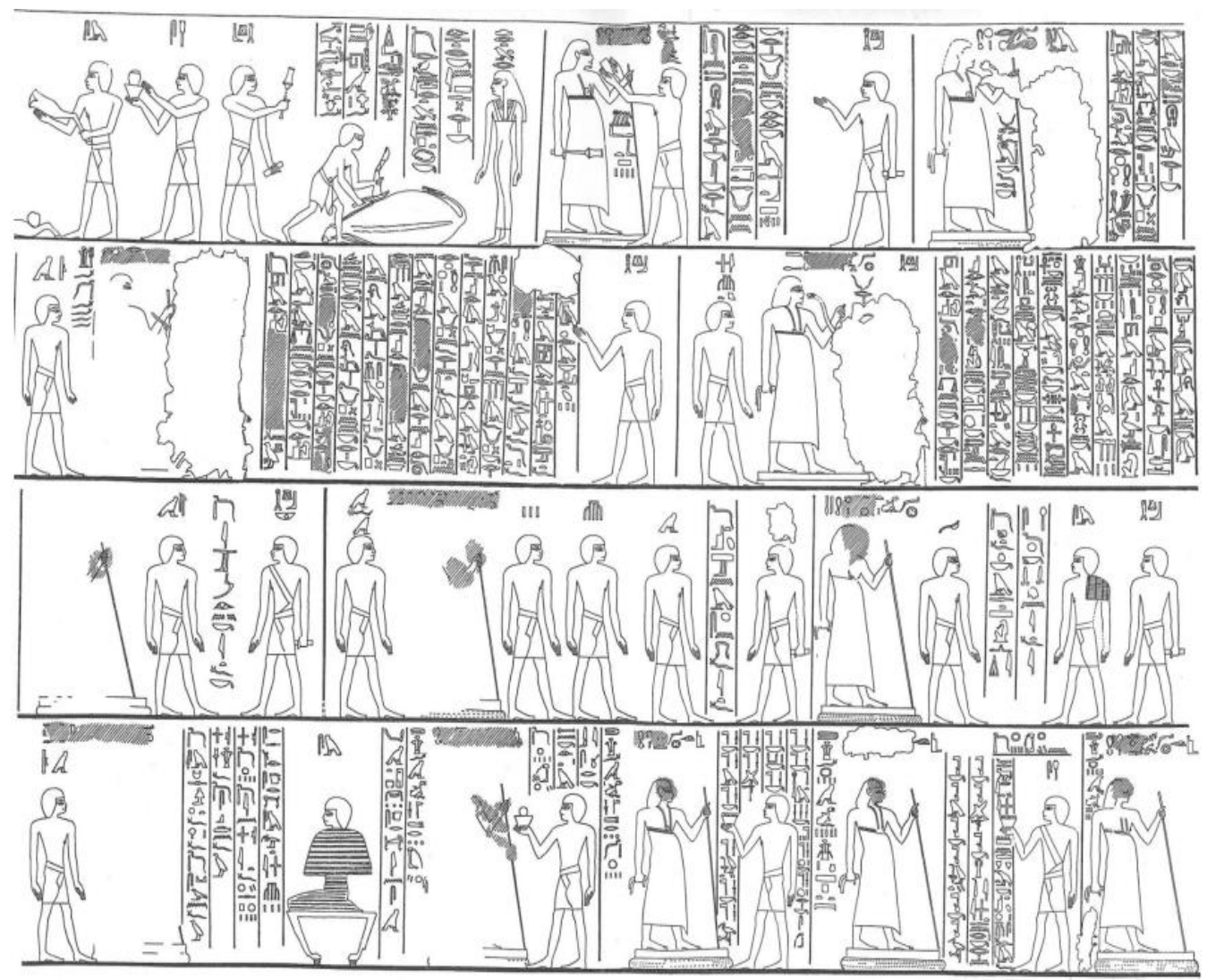

Pl. 11. The sem priest in TT 100 (Davies, 1943, Pl. CVI).

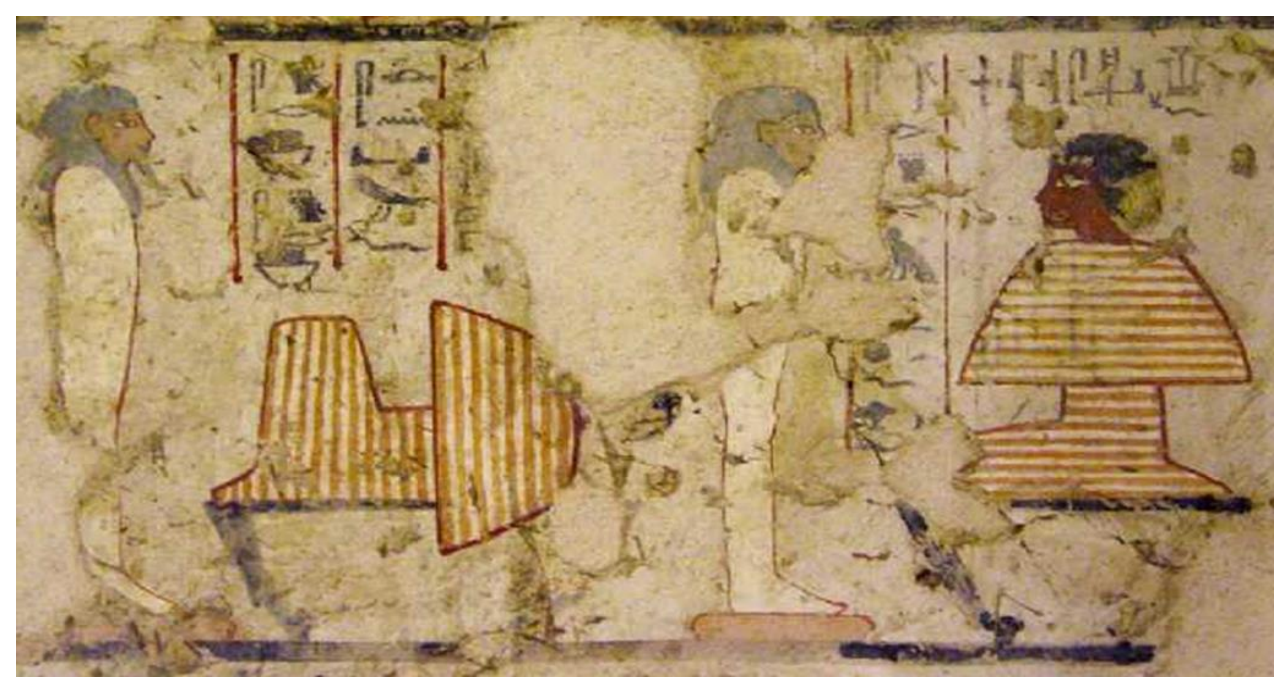

Pl. 12. The tknu in TT295 (After, Hegazy A., and Tosi, 1983). 


\section{Conclusion:}

The research concludes that the tknu was a human being was prepared to participate in the Opening of the Mouth ritual in front of the tomb so he was neither a statue nor an object. The examples in TT 295, TT100 and TT20 show clearly the identity of the tknu. He was a real character or rather a priest. So, he was neither a mere object, nor an inanimate shape, nor a sack.

The priest who played this role was preparing his participation by rites, including ointments and incense. The tknu was represented on a sledge or lying down on a bed. Sometimes he was totally or partially wrapped up in the bull hide, which is described as mskA. This person who played the role of the tknu was a sem priest as he was described in TT100 funeral scene.

We can notice that the sem priest was rarely walking in the funeral with the appearance of the $t k n u$. It was only in the funeral scenes of TT78 and other few examples that this priest was walking just behind the $t k n u$. It is known from many funeral scenes that sometime two or more sem priests were participating and performing rituals in the Opening of the Mouth ritual as in TT19, TT31. No one of the two persons who appeared behind the tknu was ever identified as sem priest or shown with the traditional panther skin of this priest, but in some funeral scenes as in TT100 (pl. 10), and in other scenes, this priest wears a kilt as the other priests in the funeral.

The tknu (sem priest) was making a sleep, then waking up after being dragged with the coffin and the Canopic chest to the tomb. During his sleep, he would see his father (the deceased) in all of his many forms the spirit world, then he is awakened to make some tasks in the rituals of the Opening of the Mouth rituals. He was looking for the soul of the deceased in the spirit world and he was bringing the powers of life, which come with Khepri (the rising sun) by a transformation ritual in the pool of Khepri.

By seeing the deceased in all his forms, which means the phases of his life (birth, maturity and death). This could help the $t k n u$ to restore all the functions of the body that weakened gradually by growing old and were lost completely by death. After the end of his role as $t k n u$, the sem changed his role to a normal sem priest with panther skin.

\section{Bibliography}

1 This research is a part from a dissertation submitted in accordance with the requirements of Minia University for the Degree of the Doctorate in Philosophy in the title of "The Funeral Procession A comparative Study between Saqqara Old Kingdom and Theban New Kingdom Private Tombs". It is under the supervision of : 1- Prof. Dr: Dimitri Laboury (Prof. of Egyptology and Archaeology-University of Liège). 2- Dr. Engy El Kilany (Assis. Prof. of EgyptologyUniversity of Minia).3- Dr. Eltayeb Abbas (Assis. Prof. of Egyptology University of Minia).

2 Delgado, S. J. M., " A contribution to the study of the tekenu and its role in Egyptian funerary ritual" in Z $Z \ddot{S} S$ CXXXVIII, 2011, p. 150; For a complete table for the 
depictions of the tknu See; Paraskeva, K., The enigmatic "tekenu”. An iconographical analysis of "tekenu" in tombs from the Old Kingdom to the Late Period, Leiden University, 2013, p. 20-35; see also, El-Shahawy, A., The Funerary Art of Ancient Egypt: A Bridge to the Realm of the Hereafter, American Univ in Cairo Press, 2005.

3 Macramallah, R., La mastaba d'ldout, Cairo, 1935, pl. 8.

4 Kanawati, N and Abder-Raziq, N., The Unis Cemetery at Saqqara, II. The Tombs of Iynefert and Ihy (reused by Idut), Oxford, 2003, p. 37.

5 TT60, Intefiker; Davies, N. de G. and Gardiner, A. H., The Tomb of Antefoker, London, 1960, pl. XXI- XXII, and the tomb of Sehetepibre; Quibell, J. E. and Petrie, W. M. F., The Ramesseum, London, 1898, p. 4 and pl. IX.

6 Paraskeva 2013, p. 77.

7 For the researcher, the rite was not performed by a statue although the scenes can give this impression. By observing all the examples, it could be an artistic vision to depict the person like that.

8 Settgast 2001, tafe. 2,7.

9 Save-Soderberg, T., Four Eighteenth Dynasty Tombs, Oxford, 1957, pl. XXVI.

10 Boussac, H., "Le tombeau d'Anna" in MMAF XVIII, Paris, 1896-1897, pl. XIII.

11 Davies, N. de G. \& Gardiner, A. H., The Tomb of Amenemhet (No. 82), London, 1915, pl. XI- XII.

12 Virey, P., "La Tombe des Vignes à Thebes" in RT XX, 1899, fig. 9

13 Nasr, W. M., "The Theban Tomb 260 of User" in SAK XX, 1993, taf. 2 \& 3.

14 Chicago Oriental Institute photos Neg. 2956.

15 Manniche, L., Lost Tombs, Londen, New York, 1988, pl. 17 n 31.

16 Griffiths, G., "The Tekenw, the Nubians and the Butic burial" in Kush VI, Khartoum, 1958, p. 119-120.

17 Seyfried, K. J., Reminiscences of the 'Butic burial' in the Theban tombs of the New Kingdom in Nigel Strudwick, N. and Taylor, J. H., The Theban Necropolis, Past, Present and Future, The British Museum Press, 2003, p. 64.

18 Seyfried 2003, p. 63.

19 Griffith 1958, p. 106-120. In reference to the Butic Burial, see: Junker, H., "Der Tanz der Mww und das Butische Begräbnis im Alten Reich", in MDAIK 9, 1940, p. 1-39; Vandier, J., "Quelques remarques sur les scenes de pelerinage aux villes saintes dans les tombes de la XVIII Dynastie" in CdE XXXVII, 1944, p. 35-61; Seyfried 2003, p. 61-68.

20 For examples see; TT100, TT96, TT20, and TT11, where the $t k n u$ appears in the same register with bull sacrifices; See Delgado 2011, p. 151, footnote, 9.

21 Seyfried 2003, p. 63.

22 For more about the significant symbolic of those colours; See Davies, W. V., Colour and Painting in Ancient Egypt, London, 2001, passim; Wilkinson, R. H., Symbol and Magic in Egyptian Art, London, 1994, p. 109.

23 Reeder, G.,"A Rite of Passage: The Enigmatic Tekenu in Ancient Egyptian Funerary Ritual ." in KMT: A Modern Journal of Egyptology XVI, no. 3, 1994, p. 58.

24 Griffiths, G. J., Solar Cycle. In D. B. Redford, The Ancient Gods Speaks, A guide to Egyptian religion, New York: Oxford University Press, 2002, p. 256.

25 Armour, R. A., Gods and Myths of Ancient Egypt. Cairo: The American University in Cairo Press, 2001, p. 193. 
26 Thomas, E., "The magic skin. A contribution to the study of the Tekenw" in AncEg I, Chicago, 1923, p. 5.

27 Thomas 1923, p. 8; G., Griffith 1958, p. 115.

28 Hornung, E., Idea into Image, New York, 1992, p. 169; Settgast, J., Untersuchungen zu Altägyptischen Bestattungsdarstellungen, Glückstadt 1963, p. 39-47.

29 Kees, H., Totenglaube und Jenseitsvorstellungen der Alten Agypter: Grundlagen und Entwicklungbis zum Ende des Mitderen Reiches, Leipzig, 1926, p. 251-253.

30 The examples are in the funeral scenes of TT 42, TT53, TT104, TT A4 and TT127 and in TT100 there are three altars for fumigation.

31 Delgado 2011, p. 152, 156.

32 See http://www.griffith.ox.ac.uk/gri/gif-files/Davies_10_15_08.jpg.

33 See Delgado, 2011, pl. VII; Hegazy, E. S., \& Tosi, M., A Theban private tomb, Tomb $N^{\circ} 295$, Verlag Philipp Von Zabern, 1983.

34 Budge, E. A. Wallis., Book of Opening the Mouth: The Egyptian Texts With English Translations, vol. I, 1909, p. 28.

35 Helck, W., "Schamane und Zauberer" In Melanges Adolphe Gutbub Montpellier: Institute d' Egyptologie,Universite Paul Valery Montpellier III, 1984, p. 103.

36 Griffiths 1958, p. 117.

37 Davies, N. de G., Five Theban tombs (being those of Mentuherkhepeshef, User, Daga, Nehemawäy and Tati, London: Egypt Exploration Fund, 1913, pls. CV, CVI.

38 Reeder, G. "The Mysterious Muu and the Dance they do" in KMT 6: 3, 1995, p. 58-59.

39 Posner, G., Sauneron, S. \& Yoyotte, J., Dictionary of Egyptian Civilization, London, 1962.

40 Reeder 1994, p. 59. 